\title{
Synthesis of squaric acid ester-containing ferrocene derivatives
}

\author{
Angélica Aguilar-Aguilar, ${ }^{a}$ Eduardo Peña-Cabrera, ${ }^{a}$ and Lanny S. Liebeskind ${ }^{b}$ \\ ${ }^{a}$ Facultad de Química. Universidad de Guanajuato. Col. Noria Alta S/N. Guanajuato, GTO. \\ Mexico 36050 \\ ${ }^{b}$ Emory University, Department of Chemistry, 1515 Pierce Drive, Atlanta, Georgia 30322. USA \\ E-mail: eduardop@quijote.ugto.mx
}

(received 12 May 04; accepted 11 Jun 04; published on the web 14 Jun 04)

\begin{abstract}
The synthesis of the first three members of the family of the squarylferrocenes is reported. Their preparation involved both the traditional squaric acid chemistry as well as the Liebeskind-Srögl cross-coupling.
\end{abstract}

Keywords: Ferrocene, squaric acid esters, cyclobutendione, Liebeskind-Srögl cross-coupling

\section{Introduction}

Ever since its discovery fifty years ago, the chemistry of ferrocene has developed dramatically. ${ }^{1}$ Its remarkable and versatile properties have allowed its use in a wide variety of applications such as homogeneous asymmetric catalysis, organic synthesis, chemical sensors, molecular electronics, and so on. ${ }^{2}$

As part of a program of developing novel ferrocene derivatives to be used as precursors of ligands in homogeneous catalysis, polymers, DNA intercalators, etc., we considered the preparation of ferrocene derivatives that contain a moiety capable of undergoing easy transformation into a variety of functionally useful systems. Squaric acid esters, and the cyclobutendiones prepared from them, have proven to be extremely useful for the synthesis of organometallic, aromatic, heteroaromatic, and non-aromatic polycyclic products. ${ }^{3}$ Thus, we envisioned that the cyclobutendione moiety, once attached to ferrocene, would be a suitable starting material for the synthesis of the aforementioned ferrocene derivatives. Our results were first disclosed in a preliminary format in $2001 .{ }^{4}$ Zora et al., ${ }^{5}$ building on our initial disclosure, recently published chemistry very similar to ours. We therefore more formally describe herein our studies of the synthesis of "squarylferrocenes". 


\section{Results and Discussion}

The 1,1'-bis-substituted derivative $\mathbf{4}$ was prepared as illustrated in Scheme $\mathbf{1}$ based on the wellknow chemistry of the squaric esters.
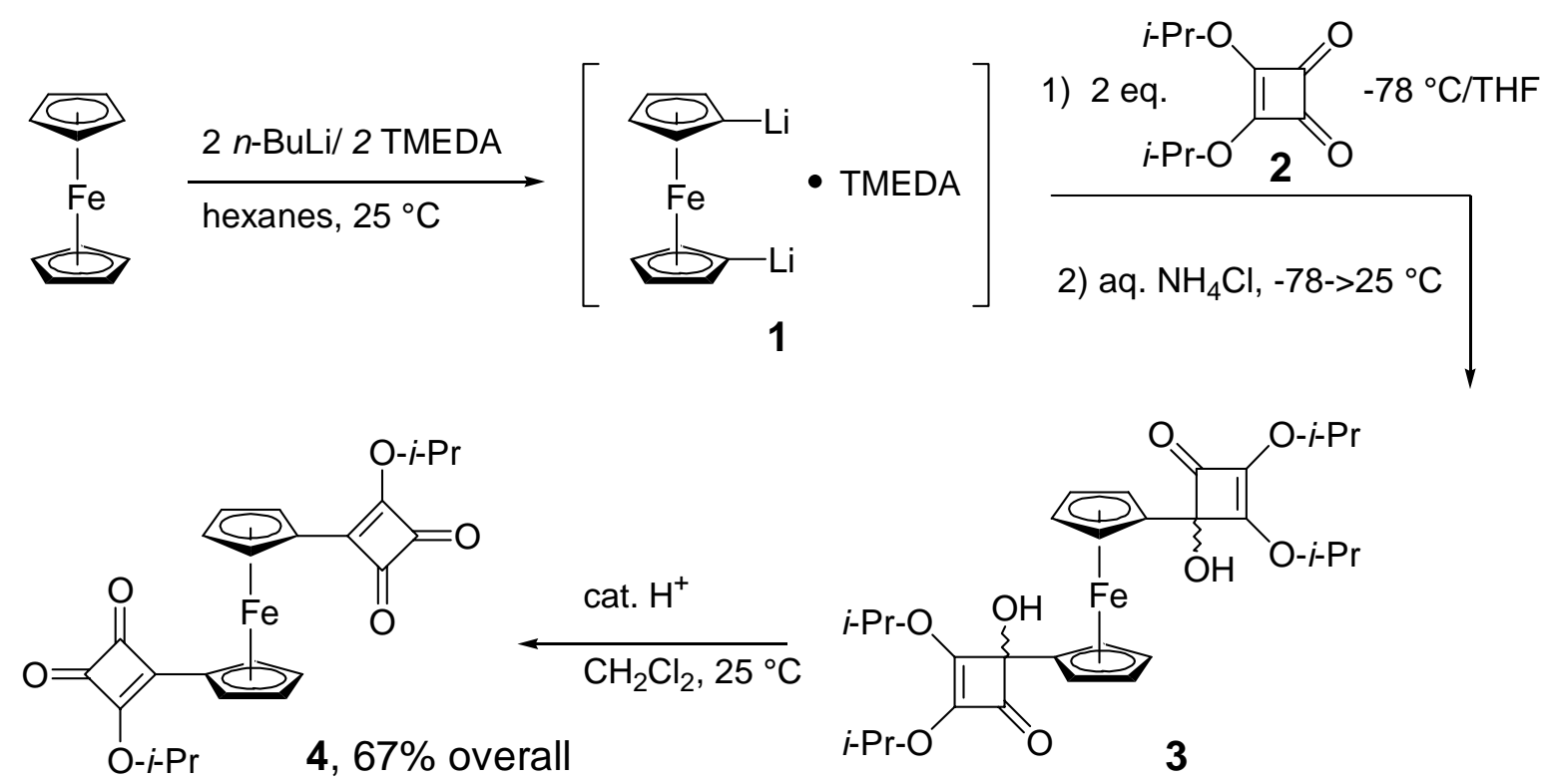

Scheme 1. Synthesis of bis-squarylferrocene 4.

Addition of 1,1'-bis-lithioferrocene $\mathbf{1},{ }^{6}$ to two equivalents of di-i-propyl squaric acid ester $\mathbf{2}$, gave a mixture of diastereomeric adducts 3. Acid-catalyzed rearrangement of the crude reaction mixture in dichloromethane gave 4 as a deep red solid in $67 \%$ overall yield .

In a similar fashion, the monosubstituted analogue 5, was synthesized in 59\% yield according to Scheme 2 using the conditions reported by $\mathrm{Kagan}^{7}$ to selectively generate monolithioferrocene from ferrocene. In this case, the best results were obtained after a trifluoroacetic anhydride quench. ${ }^{8}$

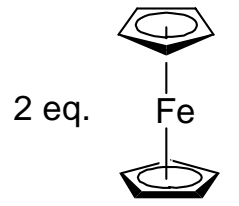

1) 1.7 eq. $t$-BuLi, THF, $0{ }^{\circ} \mathrm{C}$

2) 1 eq. $2,-78^{\circ} \mathrm{C}$, THF

3) 1.7 eq. $\left(\mathrm{CF}_{3} \mathrm{CO}\right)_{2} \mathrm{O},-78{ }^{\circ} \mathrm{C}$

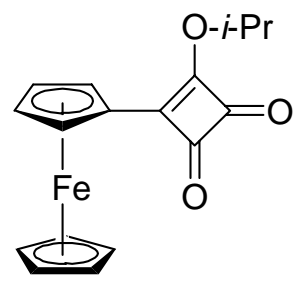

5, 59\% yield from 2

Scheme 2. Synthesis of squarylferrocene 2. 
Having been able to place one and two squaric ester units onto the ferrocene molecule, our next goal was to connect two ferrocene units to a single cyclobutendione moiety. It was envisioned that the $\mathrm{Pd}$-catalyzed, $\mathrm{Cu}(\mathrm{I})$ thiocarboxylate-mediated cross-coupling of either organoboranes or organostannanes with thioethers, i.e., the Liebeskind-Srögl cross-coupling, ${ }^{9}$ would be suitable to achieve the synthesis of 3,4-bisferrocenyl-3-cyclobutene-1,2-dione 6.

The crystalline bisarylthiocyclobutendione partner 7 was prepared in a straightforward manner in $90 \%$ yield, as shown in eq. 1 , starting from 3,4-dichloro-3-cyclobutene-1,2 dione $8 .^{10}$

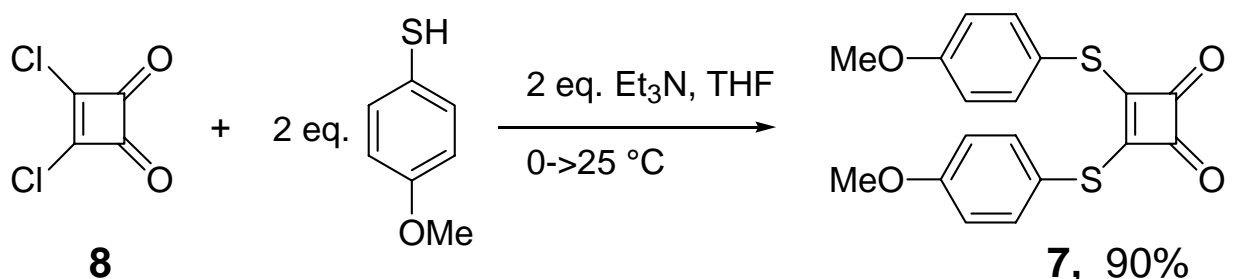

Then, 7 was coupled with ferrocenyltributylstannane ${ }^{11}$ according to eq. 2 to produce 6 in $72 \%$ yield $^{12}$ under mild reaction conditions.

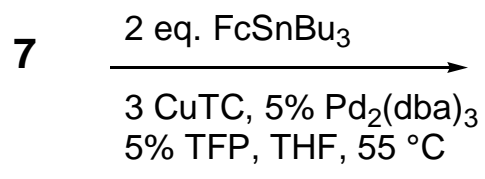

TFP= trifurylphosphine<smiles>O=C(OCl)c1cccs1</smiles>

In conclusion, we have developed a simple and efficient method to prepare derivatives $\mathbf{4 , 5}$ and 6 using readily available starting materials. The Pd-catalyzed, $\mathrm{Cu}(\mathrm{I})$ mediated cross-coupling of thioethers and ferrocenyltributylstannane complemented conveniently the traditional squaric acid chemistry for the synthesis of the first three members of the family of "squarylferrocenes". The scope and limitations of the Liebeskind-Srögl cross-coupling reaction for the preparation of more elaborate analogues of this series is underway, as well as the applications of the "squarylferrocenes" in the synthesis of polymeric materials, ion sensors and new dinuclear organometallic compounds and will be published in due course. 


\section{Experimental Section}

General Procedures. ${ }^{1} \mathrm{H}$ NMR spectra were recorded on a Varian Gemini $200(200 \mathrm{MHz})$ spectrometer in deuteriochloroform $\left(\mathrm{CDCl}_{3}\right)$ with either tetramethylsilane (TMS) $(0.0 \mathrm{ppm})$ or chloroform $(7.26 \mathrm{ppm})$ as internal reference unless otherwise indicated. Data are reported in the following order: chemical shift in ppm, multiplicities (br (broadened), s (singlet), $d$ (doublet), $t$ (triplet), q (quartet), sex (sextet), m (multiplet), exch (exchangeable), app (apparent)), coupling constants, $J(\mathrm{~Hz})$, and integration. Infrared spectra were recorded on a Perkin-Elmer FTIR 1600 series spectrophotometer. Peaks are reported $\left(\mathrm{cm}^{-1}\right)$ with the following relative intensities: $\mathrm{s}$ (strong, 67-100\%), m (medium 40-67\%), and w (weak 20-40\%).

Analytical thin-layer chromatography was performed on Merck silica gel plates with F-254 indicator. Visualization was accomplished by UV-light. THF was dried over activated $4 \AA$ molecular sieves. TMEDA was distilled from sodium and stored over activated $4 \AA$ molecular sieves. All reactions were performed under a dry $\mathrm{N}_{2}$ atmosphere in oven- and or flame-dried glassware.

\section{Experimental procedures}

1,1'-Bis $\{3-(4-i s o p r o p o x y-3-c y c l o b u t e n e-1,2-d i o x o)\}$ ferrocene (4). To a mixture of $n$-BuLi (hexane solution, $6.78 \mathrm{mmol})$ and TMEDA $(1.0 \mathrm{~mL}, 6.78 \mathrm{mmol})$ was added a hexane $(20 \mathrm{~mL})$ solution of ferrocene $(0.5 \mathrm{~g}, 2.7 \mathrm{mmol})$ via cannula under nitrogen at $25^{\circ} \mathrm{C}$. The mixture was stirred for $12 \mathrm{~h}$, after which a bright yellow precipitate of $1,1^{\prime}$-bislithioferrocene ${ }^{1}$ was formed. The suspension was left to sediment and then washed with dry hexane $(3 \times 20 \mathrm{~mL})$. The resulting yellow solid was suspended in dry hexane $(20 \mathrm{~mL})$. To a cold $\left(-78^{\circ} \mathrm{C}\right.$, dry ice-acetone) THF $(20 \mathrm{~mL})$ solution of 3,4-diisopropoxy-3-cyclobutene-1,2-dione (1.07 g, $5.4 \mathrm{mmol})$ was added drop-wise the hexane suspension of 1,1'-bislithioferrocene via cannula under nitrogen. The mixture was stirred for $30 \mathrm{~min}$ and then quenched with a saturated $\mathrm{NH}_{4} \mathrm{Cl}(15 \mathrm{~mL})$ aqueous solution at $-78{ }^{\circ} \mathrm{C}$. The mixture was allowed to reach $25^{\circ} \mathrm{C}$ and was then extracted with ether $(3$ x $20 \mathrm{~mL}$ ); the combined organic fractions were dried with anhyd. $\mathrm{MgSO}_{4}$, filtered and concentrated in vacuo. The resulting material was dissolved in $\mathrm{CH}_{2} \mathrm{Cl}_{2}(40 \mathrm{~mL})$ and a drop of conc. $\mathrm{HCl}$ was added. After TLC analysis indicated rearrangement of the adduct (ca. $1.5 \mathrm{~h})\left(\mathrm{R}_{\mathrm{f}}=\right.$ $0.23,20 \% \mathrm{EtOAc} / \mathrm{hexane}, \mathrm{UV}$-light), the solvent was evaporated. The product was purified by MPLC (EtOAc/hexane gradient) to obtain a purple-red solid $(0.84 \mathrm{~g}, 67 \%) ; \mathrm{mp} 210^{\circ} \mathrm{C}$ (dec.); IR (KBr): 3108 (m), 2929 (m), 1788 (s), 1596 (s), 1470 (s), 13854 (s), 1090 (s), 762 (m). ${ }^{1} \mathrm{H}$ RMN $\left(200 \mathrm{MHz}, \mathrm{CDCl}_{3}\right.$ ): $\delta 5.4$ (m, $J=6.2 \mathrm{~Hz}, 2 \mathrm{H}$ ), 4.95 (app. t, $J=1.8 \mathrm{~Hz}, 4 \mathrm{H}$ ), 4.6 (app. t, $J=1.8 \mathrm{~Hz}$, 4H), 1.5 (d, J=6.2 Hz, 12H). ${ }^{13} \mathrm{C} \mathrm{RMN}\left(50 \mathrm{MHz}, \mathrm{CDCl}_{3}\right): 192.7,191.9,191.3,175.7,80.1,73.8$, 70.7, 70.0, 22.8. Anal. Calcd. for $\mathrm{C}_{24} \mathrm{H}_{22} \mathrm{FeO}_{6}: \mathrm{C}, 62.36 ; \mathrm{H}, 4.80$. Found: C, 62.22; H, 4.92.

3-Isopropoxy-4-ferrocenyl-3-cyclobutene-1,2-dione (5). To a cold solution $\left(0{ }^{\circ} \mathrm{C}\right.$, ice-bath) of ferrocene $(1.4 \mathrm{~g}, 7.56 \mathrm{mmol})$ in THF $(10 \mathrm{~mL})$ under $\mathrm{N}_{2}$ was added $t$-BuLi $(6.43 \mathrm{mmol})$ via syringe. The mixture was stirred at $0{ }^{\circ} \mathrm{C}$ for $20 \mathrm{~min}$, and then added to a cold solution $\left(-78{ }^{\circ} \mathrm{C}\right.$, dry ice-acetone) of 3,4-diisopropoxy-3-cyclobutene-1,2-dione $(0.75 \mathrm{~g}, 3.78 \mathrm{mmol})$ in THF 
$(10 \mathrm{~mL})$ via cannula. The mixture was stirred at $-78{ }^{\circ} \mathrm{C}$ for $30 \mathrm{~min}$, after which the starting dione was consumed and the 1,2-adduct was formed $\left(\mathrm{R}_{f}=0.34,20 \%\right.$ EtOAc/hexane $)$. Then, the temperature was gradually increased to $25^{\circ} \mathrm{C}$ and the mixture was stirred for $1 \mathrm{~h}$. The reaction mixture was cooled to $-78{ }^{\circ} \mathrm{C}$ and trifluoroacetic anhydride $(1.35 \mathrm{~g}, 6.43 \mathrm{mmol})$ was added. The reaction mixture was stirred overnight at $25{ }^{\circ} \mathrm{C}$ and the quenched with satd. aqueous $\mathrm{NH}_{4} \mathrm{Cl}$ $(15 \mathrm{~mL})$ at $-78{ }^{\circ} \mathrm{C}$. Once the crude reaction mixture reached $25^{\circ} \mathrm{C}$, it was extracted with ether $(3$ x $20 \mathrm{~mL}$ ) and the organic fractions were combined, dried with anhyd. $\mathrm{MgSO}_{4}$, filtered and concentrated in vacuo. The product was purified by gravity column chromatography (EtOAc/hexane gradient) followed by crystallization (hexane $/ \mathrm{CH}_{2} \mathrm{Cl}_{2}$ ) to give a purple-red solid (0.73 g, 59\%); $\mathrm{R}_{f}=0.47$ (20\% EtOAc/hexane); $\mathrm{mp}=119-121{ }^{\circ} \mathrm{C}$; IR (KBr): 3110 (m), 2978 (m), 2928 (m), 1787 (s), 1728 (s) 1595 (s), 1470 (s), 1383 (s), 1096 (s), 818 (m). ${ }^{1} \mathrm{H}$ RMN (200 MHz, $\left.\mathrm{CDCl}_{3}\right): \delta 5.27(\mathrm{~m}, J=6.2 \mathrm{~Hz}, 1 \mathrm{H}), 4.96$ (app. t, $\left.J=1.8 \mathrm{~Hz}, 2 \mathrm{H}\right), 4.64$ (app. t, $J=1.8 \mathrm{~Hz}, 2 \mathrm{H}$ ), 4.17 (s, 5H), 1.52 (d, $J=6.2 \mathrm{~Hz}, 6 \mathrm{H}) .{ }^{13} \mathrm{C} \mathrm{RMN} \mathrm{(50} \mathrm{MHz,} \mathrm{CDCl}_{3}$ ): 191.9 , 191.1, 190.5, 179.9, 78.2, 72.2, 69.8, 68.1 66.9, 22.3 (s). Anal. Calcd for $\mathrm{C}_{17} \mathrm{H}_{16} \mathrm{FeO}_{3}$ : C, 62.99; H, 4.98. Found: C, $62.75 ; \mathrm{H}, 4.84$.

3,4-Bis-(p-methoxythiophenoxy)-3-cyclobuten-1,2-dione (7). To a cool $\left(0{ }^{\circ} \mathrm{C}\right) \mathrm{THF}(10 \mathrm{~mL})$ solution of dichlorodione $8(250 \mathrm{mg}, 1.6 \mathrm{mmol})$ was added $p$-methoxythiophenol $(0.4 \mathrm{~mL}$, $3.3 \mathrm{mmol})$ dropwise via syringe under $\mathrm{N}_{2}$, followed by the addition of triethylamine $(0.43 \mathrm{~mL}$, $3.3 \mathrm{mmol})$. The reaction mixture gradually reached $25^{\circ} \mathrm{C}$ and after $6 \mathrm{~h}$ was quenched with an equivalent volume of aq. $\mathrm{NH}_{4} \mathrm{Cl}$. Then, it was extracted with $\mathrm{CH}_{2} \mathrm{Cl}_{2}(3 \times 30 \mathrm{~mL}$ ), dried (anhyd. $\mathrm{MgSO}_{4}$ ), and filtered. The solvent was removed in vacuo to give a yellow solid. The remaining solid was triturated in hexane and used directly in the following reactions $(510 \mathrm{mg}, 89 \%)$. For characterization purposes, the product was crystallyzed from hexane/EtOAc $\left(\mathrm{R}_{f}=0.3\right.$, silica gel, 20\% EtOAc/hexane); mp $133{ }^{\circ} \mathrm{C}$; IR (KBr): 2939 (m), 2840 (m), 2366 (m), 1787 (s), 1807 (m) 1761 (s), 1740 (m), 1590 (s), 1571 (s). ${ }^{1} \mathrm{H} \mathrm{RMN} \mathrm{(200} \mathrm{MHz,} \mathrm{CDCl}_{3}$ ): $\delta 7.50$ (d, J= $8.94 \mathrm{~Hz}, 2 \mathrm{H}$ ), $6.90(\mathrm{~d}, J=8.89 \mathrm{~Hz}, 2 \mathrm{H}), 3.80(\mathrm{~s}, J=1.8 \mathrm{~Hz}, 3 \mathrm{H}) .{ }^{13} \mathrm{C} \mathrm{RMN}\left(50 \mathrm{MHz}, \mathrm{CDCl}_{3}\right): 188.2,186.7$, 161.7, 136.4, 115.0, 66.1, 55.7. Anal. Calcd for $\mathrm{C}_{18} \mathrm{H}_{14} \mathrm{O}_{4} \mathrm{~S}_{2}$ : C, 60.32; H, 3.94; S, 17.89. Found: C, 59.99; H, 3.92; S, 17.58 .

3,4-Bisferrocenyl-3-cyclobuten-1,2-dione (6). To a deoxygenated $\left(\mathrm{N}_{2}\right.$ purge) THF (3 mL) solution of ferrocenyltributylstannane $(0.394 \mathrm{~g}, 0.83 \mathrm{mmol})$ and and bisthiodione $7(0.100 \mathrm{~g}$, $0.28 \mathrm{mmol}$ ) was added $\mathrm{Pd}_{2}(\mathrm{dba})_{3}(13 \mathrm{mg}, 0.014 \mathrm{mmol})$, trifurylphosphine $(3 \mathrm{mg}, 0.014 \mathrm{mmol})$, and CuTC (160 mg, $0.84 \mathrm{mmol})$. The mixture was stirred under $\mathrm{N}_{2}$ at $55^{\circ} \mathrm{C}$ for $2 \mathrm{~h}$, then the solvent was was removed under vacuum. The product was purified by gravity column chromatography (EtOAc/hexane gradient) to give a deep red solid (91 mg, 72\%). $\mathrm{R}_{f}=0.6(20 \%$ EtOAc/hexane, silica gel); mp $189{ }^{\circ} \mathrm{C}$. IR (KBr) 3436 (s), 2851 (m), 2360 (m), 1771 (s), 1575 (s), 1489 (s), 1284 (s). ${ }^{1} \mathrm{H}$ NMR (200 MHz, $\left.\mathrm{CDCl}_{3}\right): \delta 5.1(\mathrm{~m}, 4 \mathrm{H}), 4.7(\mathrm{~m}, 4 \mathrm{H}) 4.26$ (s, 10H). ${ }^{13} \mathrm{C} \mathrm{RMN}\left(50 \mathrm{MHz}, \mathrm{CDCl}_{3}\right): 196.4,187.3$, 73.4, 70.8, 69.9, 69.4. Anal. Calcd for $\mathrm{C}_{24} \mathrm{H}_{18} \mathrm{Fe}_{2} \mathrm{O}_{2}$ : C, 64.04; H, 4.03. Found: C, 64.03; H, 4.04. 


\section{Acknowledgements}

Financial support from CONACyT (Mexico) Grant No. 27600- E, CONCyTEG (Mexico) Grant No. GTO-2003-C02-11921 is gratefully acknowledged as well as graduate scholarship for A. A.A. The synthesis of the ferrocenylcyclobutenediones $\mathbf{4}$ and $\mathbf{5}$ was carried out by author E. P-C during a stay at Emory University funded by NIH grant \#CA40157.

\section{References}

1. For recent advances on ferrocene chemistry see the special issue of the Journal of Organometallic Chemistry on the $50^{\text {th }}$ Anniversary of the Discovery of Ferrocene $J$. Organomet. Chem. 2001, 637.

2. Togni, A.; Hayashi, T., Eds; Ferrocenes: Homogeneous Catalysis, Organic Synthesis, Material Science; VCH: New York, 1995.

3. (a) Moore, H. W. ; Yerxa, B. R. In Synthetic Utility of Cyclobutenediones; Halton, B., Ed.; JAI Press: Greenwich, CT, 1995; Vol. 4, pp 81. (b) Liebeskind, L. S. Tetrahedron Symp. Print 1989, 45, 3053. (c) Koo, S.; Liebeskind, L. S. J. Am. Chem. Soc. 1995, 117, 3389. (d) Sun, L.; Liebeskind, L. S. J. Am. Chem. Soc. 1996, 118, 12473. (e) Paquette, L. A.; Doussot, P. Res. Chem. Intermed. 1996, 22, 767. (f) Ohno, M.; Yamamoto, Y.; Eguchi, Synlett 1998, 1167.

4. Peña-Cabrera, E.; Villanueva-Rendón, A. D.; Robles-García, J.; Mendoza-Díaz, G.; Liebeskind, L. S. the $11^{\text {th }}$ IUPAC Symposium on Organometallic Chemistry Directed Towards Organic Synthesis. Abstract Book P050 Taipei, Taiwan, July 2001.

5. Zora, M.; Yucel, B.; Acikalin, S. Tetrahedron Lett. 2003, 44, 2237.

6. (a) McCulloch, B.; Brubaker Jr.; C. H. Organometallics 1984, 3, 1707, (b) McCulloch, B.; Ward, D. L.; Woolins, J. D.; Brubaker Jr.; C. H. Organometallics 1985, 4, 1425.

7. Guillaneux, D.; Kagan, H. J. Org. Chem. 1995, 60, 2502.

8. Onofrey, T. J.; Gomez, D.; Winters, M.; Moore, H. W. J. Org. Chem. 1997, 62, 5658.

9. (a) Liebeskind, L. S.; Srogl, J. S. Org. Lett. 2002, 4, 979. (b) Egi, M.; Liebeskind, L. S. Org. Lett. 2003, 5, 801. (c) Alphonse, F.-A.; Suzenet, F.; Keromnes, A.; Lebret, B.; Guillaumet, G. Org. Lett. 2003, 5, 803. (d) Savarin, C.; Srogl, J.; Liebeskind, L. S. Org. Lett. 2001, 3, 91. (e) Savarin, C.; Liebeskind, L. S. Org. Lett. 2001, 3, 2149. (f) Srogl, J.; Liebeskind, L. S. Org. Lett. 2002, 4, 979. (g) Kusturin, C. L.; Liebeskind, L. S.; Neumann, W. L. Org. Lett. 2002, 4, 983. (h) Liebeskind, L. S.; Srogl, J.; Savarin, C.; Polanco, C. Pure Appl. Chem. 2002, 74, 115. (i) Egi, M. ; Wittenberg, R.; Srogl, J.; Liebeskind, L. S. Org. Lett. 2003, 5, 3033.

10. Yamamoto, Y.; Shirasaki, Y.; Eguchi, S. J. Chem. Soc. 1993, 263.

11. Liu, C.; Lou, S.; Liang, Y. Synth. Comm. 1998, 28, 2271, also see ref. 7. 
12. For preliminary results, see: Peña-Cabrera, E.; Aguilar-Aguilar, A.; Hernández-Barba, A.; Rodríguez-Cendejas, C.; Liebeskind, L. S. Abstracts of Papers 20th Int. Conf. Organomet. Chem., Corfu, Greece, 7-12 July, 2002; p 194. 